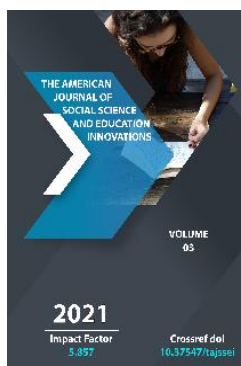

\title{
Harmony Of Art In Architecture Of Uzbekistan
}

\section{Sultanova Dilshoda Namazovna}

Doctor Of Architectural Sciences, Associate Professor Of Fine Arts, Samarkand State Architecture And Civil Engineering Institute Named After Mirzo Ulughbek, Samarkand, Uzbekistan

Journal Website:

http://theamericanjour

nals.com/index.php/taj

ssei

Copyright: Original content from this work may be used under the terms of the creative commons attributes 4.0 licence.

\section{ABSTRACT}

The article describes the artistic features of harmonizing the visual and artistic means of Uzbekistan based on the analysis of theoretical sources and the practice of architecture. Also, the author's position on the definition of creation is outlined as a generalization of innovative tools in architecture, whose development is given taking into account national traditions in synthesis with modern trends.

\section{KEYWORDS}

Harmony of art, design, interior, application of innovative means, modern, traditional, local conditions, national features, trends, analysis, decor, practice, ornament, form.

Relevance of the topic. Nowadays, significant research is being carried out in achieving harmony of visual and artistic means, using 
"genuine styles" in this area to determine the role of increasing expressive artistic means of agitation and propaganda, as well as huge searches are underway in the field of "architectural and artistic image." This study today focuses on strengthening the emotional influence of architecture in the application of visual and artistic means. In most cases, the term "art and image" is used together, despite the variety of architectural materials and the ways in which they are used effectively and the influence them in the development of modern urban culture [1-5].

Degree of study of the problem. The study of the history of architecture and urban planning in Central Asia in general and Uzbekistan, in particular, began more than a century ago. Since then, the results of research aimed at studying certain features of the development of cities in our region have been published in the form of scientific articles, monographs and dissertations. When studying the processes of development of harmonization of visual and artistic means.

Today, based on the scientific works of prominent scientists (T. Well, F. Moiser Germany, J. Frey - France, M. G. Barkhin, N. V. Baranov, B. A. Glauddinov, I. G. Lezhava, V.A. Lavrov, S.M. Mamazhonova, R.S.Mukimov, Yu.V. Raninsky, G.P. Stepanov, V.P. Tolstoy, O.A. the foundations of the problem of harmonization of visual and artistic means in architecture.

The purpose of this study is the definition of traditional ways of mutual harmonization of visual and artistic means in the architecturalspatial and urban environment of
Uzbekistan's architecture. To achieve this goal, the following

\section{Research Objectives:}

- To study the genesis of the harmonization of visual and artistic means in the architecture of Uzbekistan;

- To determine the ways of using visual and artistic means in the traditional architecture of Uzbekistan;

The subject of the research is traditional, modern and promising techniques and methods of harmonization of visual and artistic means in individual buildings and in the urban environment as a whole [6-11].

\section{The scientific novelty of the research:}

- It has been established that the genesis of the use of visual and artistic means in the architecture of Uzbekistan originates from the Paleolithic era and its successive development has been established - cave and rock carvings, ancient and early medieval wall paintings, medieval book miniatures and architectural and epigraphic ornaments, varieties of modern artistic means by composing plot compositions;

- It is proved that the reflection of the influence and greatness of the rulers of the ancient period was displayed through pictorial symbols;

\section{The practical results:}

- Revealed the genesis of the use of visual and artistic means in the architecture of Uzbekistan; 
- A system of harmonization of visual and artistic means with architectural compositions in architectural practice has been developed;

- The proposal for the phased placement of visual and artistic means (on the scale of the republic, region, city, separate building) in the architectural and urban environment has been substantiated;

- The compositional properties, models and parametrization of cities, divided by their classifications, necessary for decoration, have been clarified;

The reliability of the research results is proved by a scientific approach recognized by the science of the history of architecture and the use of literature on the primary sources of material culture, archival sources, as well as the practical application of the research results, the presented conclusions, proposals and recommendations.

\section{The scientific and practical significance of the} research results. The scientific significance of the research is determined by the fact that there are ample opportunities for enriching knowledge in the field of history of architecture, as well as the development of materials for the educational process, including textbooks and textbooks on the disciplines "History of Art and Culture" and "History of Art of Uzbekistan", organizing seminars for specialists in higher educational institutions and in refresher courses.

The practical significance of the research results serves to improve the quality of design solutions developed for the preservation, restructuring and modernization of historical cities, which provides an opinion on the placement of buildings and the harmonization of visual and artistic means in settlements, on the use of symbolic elements on the scale of the republic, region, city and individual building, on the selection of subjects and techniques of visual and artistic means in the exteriors and interiors of buildings and structures.

\section{THE MAIN CONTENT}

1. Ways of forming artistic means in the architecture of Uzbekistan considers the history of architecture, the genesis of graphic and artistic means, the emergence of ornaments in the exterior and interior of buildings and the experience of using artistic means in the territory of ancient, early middle Ages and medieval Central Asia. The harmonious combination of architecture and nature, the creation of a full-fledged environment for the allaround development of the individual remains the cherished ideals of creativity [12-19]. Harmony is an amazingly capacious concept. The ancient myth also praised the beautiful Harmony, which was the daughter of the goddess of beauty. This sublime image eventually became a symbol of everything perfect, slender and proportionate. Plato also argued that “... there is nothing beautiful without harmony. The formation of various means and techniques of fine art in the interior was subordinated to the laws of architecture, art interdependent with sculpture and decorative and applied elements, which is considered a kind of period in the development of cities in Central Asia. 
In the 9th-12th centuries, the techniques of artistic brickwork from shaped bricks were used in the interiors and exteriors of mosques and mausoleums. In the composition of the interiors, along the surface of the walls, bricks were laid in the form of a Christmas tree, chess, paired (for example, in the Samanid mausoleum). In the mosaics of the exterior of Central Asia, stylized floral and plant motifs were prioritized; in many cases, polychrome ornaments of a solemn mood were created against a dark blue background. By the 16th century, after the prohibition of depicting living creatures in monumental size, in Central Asia, the only direction where they could be applied was book miniatures [20-25]. Formed during the reign of Amir Temur, compositions with domed rooms, a portal and a suite were widely used in the cities of Shakhrisabz, Samarkand, Bukhara, Tashkent, Herat and Turkistan. During the period under review, more than 50 types of domes were used, including Turkistoni, Balkhi, Mirzoi, Chortarkh, etc.

\section{2. "Traditions of the use of visual and artistic means in medieval architecture (early XVI-XX centuries)."}

At the end of the 5th-6th centuries, in most of the newly built walled cities, interiors were decorated with wood carvings and wall paintings. These traditions in northern Bactria are found in the following ruins of monuments - Bolalyktepa, Zhumalaktepa, Dalvarzintepa and Tuprokkala in Khorezm. The traditions of mural painting in Central Asia did not disappear even in the Middle Ages when the fine arts developed in two directions: in the palace interior and in manuscript miniature books. Samarkand artists in the iconography of painting buildings paid attention not only to the vertical and horizontal sides, depicting everything orthogonally, in symmetry. Hence the conclusion: the iconographic, artistic, ideological and colouristic foundations of monumental painting developed in conjunction with the traditions of the oriental school of art [26-29].

With the formation of the use of visual and artistic means in modern architecture, the genre of wall painting retains its continuity. In this case, it is desirable that the building was "specially designed", taking into account the use of visual and artistic means.

Acquaintance with the diaries of the Spanish ambassador to the court of Amir Temur - Ruy Gonzales de Clavijo says the same thing. Describing the halls of the palace of Amir Temur, he mentions that the walls of the palace were covered with monumental and picturesque frescoes.

In his book "From the history of the fateful incidents of Temur" Ibn Arabshox writes: "In Samarkand, Temur created many gardens, built high and solid palaces. They were all neat, amazingly beautiful and delightful. The written (calligraphic) group consisted of ornamental epigraphic decorations in the outer and inner parts of public buildings. Ornaments of this kind in the architecture of Central Asia were widespread mainly starting from the X-XI centuries.

They were usually used on the outer part of the portal - in Kitabs, in the drum of the dome, on gates and doors, columns, as well as in the inner and outer walls of the building, ceiling, door panels, in the altar and on tombstones (epitaph). The inscriptions taken from the Qur'an and hadiths were performed in the 
Arabic alphabet consists of - religious, philosophical and instructive themes. On the portals of public buildings, there are mainly zoomorphic tiled ornaments. Among which there are real and fantastic images of animals phoenix, dragon, deer [30-33]. They meet in the Sherdor and Nadir Devonbegi madrasahs in Samarkand, in the Abdulazizkhan and Nadir Devonbegi madrasahs in Bukhara. About the use of ornaments, except for the mausoleum of Amir Temur and the Timurids and the cathedral mosque of Amir Temur (Bibikhanim), it would be appropriate to describe in detail the artistic means of the kyoshka Aksaray.

During the reign of Amir Temur, as a result of the acceleration of the construction process, it was important to fill the empty inner surface of the dome with a new artistic method. During this period, a new direction was the "kundal" technique, which, as a relief interior decoration, passed into interior architecture thanks to artistic embroidery. The analysis revealed that the art plots on the wall, covering the historical processes of the spiritual formation and development of the people, are skillfully drawn by the masters of the brush.

These murals are of great importance for educating young people in the spirit of national ideology in the traditional "convention" and "symbolism". The emergence of modern schools of monumental painting indirectly and directly depends on them. Over time, the ideological task of art has turned into a spiritual base, an important basis for the construction of independent Uzbekistan. If the primary task of monumental painting is artistry, then it is possible to solve its ideological and ideological issues by reflecting the plots of history and national culture. For example, in the palace of Ikhshid Varhuman on Afrasiab, the murals reflected the life and strength of the state, their international relations and the spirituality of the government.

The monumental paintings of Amir Temur's palace and instructive epigraphic inscriptions helped foreign guests to quickly understand the essence of these books.

\section{3. "Analysis of the use of visual and artistic means in the urban planning of modern Uzbekistan (general overview).}

The origins of sculpture, which arose in ancient times in the East, in particular in Central Asia, originate from fetishism, idolatry, fire worship and other objects serving as an object of religious worship. Archaeological finds indicate that in the temples and living rooms of noble people, the works of wall paintings in monumental sizes were performed in harmony with the interior.

In the premises of public buildings, round sculptural figures were installed on a platform or in the form of high relief on the surface of the inner wall, being organically connected with the interior architecture of this room. The revival of sculpture in modern Uzbekistan dates back to 1920-1930. It is especially noteworthy that the art of sculpture of the period of independence generalizes centuriesold artistic, national and modern traditions and foreign practice.

They also reflected stylistic trends such as academic realism, avant-garde and postmodernism. The general plan of the cities of independent Uzbekistan takes into account the program of decorating the main streets of 
the city with graphic means containing the following elements: town-planning units (different areas of three types - mahalla, district and city-wide), the connection of the direction of main roads and streets. In the thematic plan, the style of decoration with pictorial means of agitation and propaganda is studied as 4 groups (historical, international holidays, architectural and artistic monuments and the achievements of the country's independent development).

\section{CONCLUSION}

As a result of the research carried out, we came to the following conclusion:

1. The use of visual and artistic means in architecture originated from ancient times - from the first paintings in cave dwellings of the Paleolithic period. Style - the commonality of lines, strokes and the choice of compositions in the images of horsemen of medieval wall painting and book miniatures shows that for the first time in the art of monumental painting in Uzbekistan, the scientific foundations of artistic continuity have been determined.

2. Generalization of the results of scientific research showed that artistic and visual means, developing in close connection with architecture, reflected the ideological views of the time by the effort of emotional impact in Central Asian architecture. The famous murals of the 7 th century Afrasiab settlement in Sogdiana were used as additional pictorial techniques that reflected the ideological policy of their time.

3. To strengthen the ideological and artistic power of architecture, at first, wall painting and sculpture were used. Starting from the 9th century, decoration and strengthening of the monumentalization of the forms of portals, minarets, columns and domes have been developing. In the Middle Ages, along with the aforementioned means, calligraphic ornament and other pictorial means propagating the ideology of power were developed;

4. The use of recreated types of visual and artistic means, by the method of manual labour, exceeds the possibility of organic synthesis in architecture. Tradition reflecting at the root the urban image in the environment of cultural harmonization of local and national genetic factors of architecture, is synthesized with modern conditions and styles. Here it is necessary to achieve overall stylistic integrity.

\section{REFERENCES}

1. Sultanova D.N. (2020). Ways of harmonization of visual and artistic means in the architecture of Uzbekistan (tradition and modernity). Architecture fan doktori (DSc) diss. abstracts. TAQI.

2. Sultanova D.N. (2015) Solution of the artistic image of the building of the Academic Theater named after Alisher Navoi in Tashkent. Questions of the humanities, (heading: Art history). Moscow. 2 (77). pp. 130-135.

3. Sultanova, D.N. (2013). The use of architectural decor and artistic plastics in the medieval architecture of Uzbekistan and its place in the artistic culture of Central Asia. Young Scientist, (12), 719-723. 
4. Abdurashidovich, X. A., \& Nigmanovna, M. F. (2019). Access to electronic educational resources in the education system. European Journal of Research and Reflection in Educational Sciences Vol, 7(12).

5. Elmurzaevich-TSPU, M. O., \& Rustamovich, A. J. (2019). The benefits of using information technology in the education system. European Journal of Research and Reflection in Educational Sciences Vol, 7(12).

6. Urokova, S. B. (2020). Advantages and disadvantages of online education. ISJ Theoretical \& Applied Science, og (89), 34-37.

7. Urokova, S., \& Tuhtashev, U. (2019). Trends of electronic education development. European Journal of Research and Reflection in Educational Sciences, 7(12), 768-771.

8. Hasanov, A. A., \& Gatiyatulina, R. M. (2017). Interdisciplinary Communication as a Didactic Condition of Increasing the Efficiency of Educational Process. Eastern European Scientific Journal, (5).

9. Sharipov, D., Abdukadirov, A., Khasanov, A., \& Khafizov, O. (2020, November). Mathematical model for optimal siting of the industrial plants. In 2020 International Conference on Information Science and Communications Technologies (ICISCT) (pp. 1-3). IEEE.

10. Ravshanovna, P. N., \& Abdurashidovich, K. A. (2019). Role of innovation in school development. European Journal of Research and Reflection in Educational Sciences Vol, 7(12).
11. Hasanov, A. A. (2020). Peculiarities of preparing teachers for the development and use of e-learning resources. Theoretical \& Applied Science, (9), 15-17.

12. Khasanov, A. A. (2018). Didactic Foundations of Interdisciplinary Connections at Subject Teaching. Eastern European Scientific Journal, (6).

13. Suleymanova, R. M. (2020). Technological process of creation of electronic educational resources. Theoretical \& Applied Science, (9), 3840.

14. Gulomova, N. (2021). Use of interactive methods for students in teaching drawing lessons (on the example of views). Academicia: an international multidisciplinary research journal, 11(1), 1637-1642.

15. Gulomova, N., \& Saidaliyev, S. (2020). Development of Emergency Image in Students Psychological-Pedagogical Problems. International Journal of Progressive Sciences and Technologies, 18(2), 181-186.

16. Zikirov, M. C., Qosimova, S. F., \& Qosimov, L. M. (2021). Direction of modern design activities. Asian Journal of Multidimensional Research (AJMR), 10(2), 11-18.

17. Razzakov, S. J., Rakhmanov, B. K., \& Akhmedov, J. D. (2021). Study Of The Influence Of Light Weather On The Mechanical Properties Of Para-Aramid Filaments. The American Journal of Engineering and Technology, 3(04), 35-41.

18. Sobitovich, B. S., Ahmedovich, M. N., Erpolatovich, T. N., Khotamovna, G. N., \& Jurakhanovna, T. D. (2020). 
Principles of using scientific discoveries in modernization of the art education system. Journal of Critical Reviews, 7(11), 2020.

19. Valiev, A. (2021). About the features of the perspective of simple geometric shapes and problems in its training. Збірник наукових праць SCIENTIA.

20. Tashimov, N., \& Samandar, Z. (2021). Improving the quality and efficiency of teaching descriptive geometry in a credit-modular system. ACADEMICIA: An international multidisciplinary research journal, 11(2), 730-733.

21. Jabbarov, R. (2021, March). Priorities for the development of painting. In Конференции.

22. Jabbarov, R. (2021, April). Developing students'creative abilities through teaching" landscape color picture" in higher education system. In Конференции.

23. Zakirova, G. M. Q., \& Axmedov, J. D. (2021). Architectural appearance of khudoyorkhan palace: requirements for preservation and restoration. Scientific progress, 1(6), 717-719.

24. Abdullaev, I. N., Akhmedov, Z. D., Rakhmanov, B. K., \& Zhurabaeva, R. T. (2020). State and prospects of production and operation of synthetic woven belts (table) for load-handling devices (hd) in the republic of Uzbekistan. Journal of Tashkent Institute of Railway Engineers, 16(4), 106-109.

25. Salimov, A. M.; Qosimova, Sh. F.; and Tursunov, Q. Q. (2020) "Features of the use of pilgrims for tourism in the Fergana region," Scientific-technical journal: Vol. 24: Iss. 4, Article 6.
26. Kosimova, S. H., \& Kosimov, L. M. (2020). Principles of forming a gardenpark landscape design around historical monuments of the fergana valley. ACADEMICIA: An International Multidisciplinary Research Journal, 10(6), 1582-1589.

27. Qosimov, L. M., Qosimova, S. F., \& Tursunov, Q. Q. (2020). Specific aspects of using Ferghana region's pilgrims for touristic purposes. Academic research in educational sciences, (3).

28. Malikov, K. G. (2020). Theory and practice of construction of axonomertic projects. European Journal of Research and Reflection in Educational Sciences Vol, 8(9).

29. Akhmedov, M. U., \& Kholmatova, F. (2021). Formation of creative processes in students through teaching composition in fine arts. Збірник наукових праць $\Lambda$ 'ОГО

30. Djumaevich, K. K., \& Toshkuvatovich, D. S. (2021). The book of principle of a human specialist. Annals of the Romanian Society for Cell Biology, 7077-7088.

31. Talipov, K. N. (2021). Is graphics important in painting?. Academicia: an international multidisciplinary research journal, 11(1), 984-990.

32. Talipov, N. X., \& Aliev, N. S. (2021). The importance of perspective in teaching art to future fine arts teachers. Asian Journal of Multidimensional Research (AJMR), 10(2), 97-103.

33. Tulanova, D. (2021). Imaginary line in landscape painting of Uzbekistan. Academicia: an international multidisciplinary research journal, 11(2), 773-778. 